\title{
Direct Utilization of Geothermal Energy in Menengai, Kenya: Pilot Project for Drying Food Commodities in Lesiolo, Nakuru
}

\author{
Allen Haryanto Lukmana ${ }^{1 *}$ \\ 1) Petroleum Engineering Department, UPN "Veteran" Yogyakarta \\ * email korespondensi: allenharyanto45@upnyk.ac.id
}

\begin{abstract}
Kenya is a developing country highly dependent on economic rotation in agricultural sector with main commodities corn, tea and fruits. In order to maintain quality of commodity within a certain period, a drying process is needed. Purpose of drying is to reduce moisture content of a commodity to a certain level. Alternative energy that can be used for drying activities in Kenya is geothermal energy. In assessing direct utilization of geothermal energy, a pilot project was made in Lesiolo, Nakuru by utilizing heat energy from the Menengai geothermal waste fluid area, Nakuru.

Drying process can utilize brine from separator or condensate from power plant by using a heat exchanger to get required drying temperature. One drying room can hold about 20 tons in ambient air conditions. This dryer is shaped like a tunnel where hot air will flow from each side of drying chamber. Food commodities used in this project are wheat, corn and barley. Heat energy needed to dry each of these food commodities comes from geothermal waste fluid that enters heat exchanger with a minimum input temperature of $130 \mathrm{oC}$ and an output of 93oC. Mass flow rate needed to dry every $30 \mathrm{~m} 3$ of commodity is $2 \mathrm{~kg} / \mathrm{s}$
\end{abstract}

Keywords: commodity drying; geothermal fluid disposal; heat exchanger

\section{INTRODUCTION}

Kenya is a country located in East Africa and has a tropical climate that causes the growth of various types of plants. This is what causes the sector

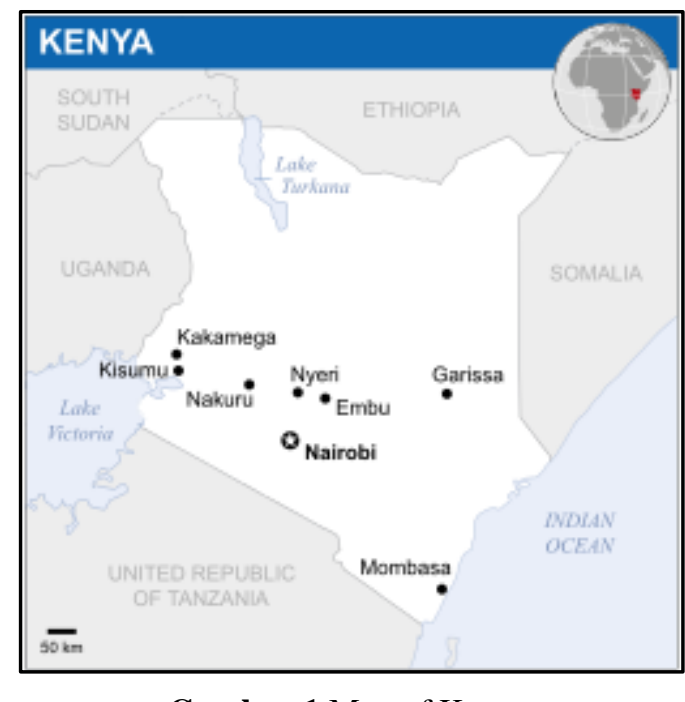

Gambar 1 Map of Kenya

agriculture contributed a significant contribution of GDP (Gross Domestic Product) in Kenya to 24\% (Kinyanjui, 2013). Agricultural sector in Kenya consists of $32 \%$ of food crops. Corn production has a proportion of $15 \%$ of food crop production in Kenya (Kinyanjui, 2013). In addition to domestic consumption, agricultural sector also exports to other countries. $65 \%$ of agricultural exports are coffee and tea. Food commodities such as corn, tea, coffee and vegetables need a drying process so that the quality of these products can be maintained within a certain period of time and especially for export commodities. The process of drying food commodities requires heat energy obtained from various 
sources. The country of Kenya currently uses thermal energy derived from diesel and sunlight to carry out the drying process. Diesel energy is usually used in grain drying plants and solar energy is used to dry coffee plants.

The use of energy derived from fossil fuels has many negative effects on the environment and is not renewable while use of solar energy has limited weather factors in certain areas. Especially for countries that have a tropical climate like Kenya. This underlies that energy use for drying activities be encouraged towards the use of alternative energy.

Alternative energy that is very potential to be used in Kenya is geothermal energy. Potential for geothermal energy in Kenya area estimated 15,000 MW with an installed capacity used for electricity generation of 130 MWe (Olkaria) and in the Eburu area of 2.5 MWe (A.Omenda, 2007). Brine and condensate from separators and cooling towers can be used as a source of heat for the process of drying food plants. Heat from brine and condensate will pass through a heat exchanger and then be changed to a certain temperature in accordance with needs of the drying temperature for each commodity. Drying process using heat from brine and condensate has been successfully carried out in various countries and one of them is carried out by Taupo Lucerne Company, New Zealand. Companies based in Taupo, North New Zealand use waste fluid from separators and cooling towers from the Ohaaki geothermal area power plant to dry various commodities such as Lucerne (alfalfa), Timber and Pinus Radiata (Pirrit \& Dunstall, 1998).

A pilot project for process of drying using heat energy from the waste fluid power plant can be done in the Lesiolo area, Nakuru (close to the Menangai geothermal area, Nakuru). This area is a location for drying wheat, corn and barley. Currently the heat energy used for the drying process comes from diesel fuel. In this paper we will discuss the technical study of the mechanism of drying process by using heat from fluid left over from the power plant in Menengai geothermal area, Nakuru with a generating capacity of 400 MWe which will be operational by the end of 2015 (Wetang'ula, 2012).

\section{METHODS}

\section{BASIC ASSUMPTIONS}

There are several basic assumptions used in this study:

- At present Menangai geothermal field, Kenya is still under development and will be operational by the end of 2019 (Wetang'ula, 2012). Some data needed for the mechanism of geothermal fluid production and injection refers to the Olkaria geothermal field.

- The drying flow diagram mechanism refers to utilization of geothermal energy by The Taupo Lucerne Company, New Zealand.

\section{PRODUK HASIL PENGERINGAN}

The types of commodities to be carried out in drying process in this pilot project are wheat, corn and barley. Drying process is carried out to reduce the moisture content of each commodity to a value so that it can maintain the quality of the commodity within a certain period. During the drying process, material in each commodity will experience changes in physics, chemistry and biology. This will change the shape of the commodity in terms of texture, color, taste and nutritional value (Kinyanjui, 2013).

Moisture Content represents the amount of water content in a material. In the study of drying, moisture content is relative to the dryness of a material. Drying carried out in a pilot project in Kenya focused on regulating the moisture content in each grain into a certain value. The following are moisture content values needed for several commodities:

Tabel 1 Some moisture content values for storing commodities within a certain period (Kinyanjui, 2013)

\begin{tabular}{|c|c|c|}
\hline Crop & \multicolumn{2}{|c|}{ Moisture content for storage (\% w.b) } \\
\cline { 2 - 3 } & $\begin{array}{c}\text { For one year } \\
\text { storage }\end{array}$ & $\begin{array}{c}\text { For two year } \\
\text { storage }\end{array}$ \\
\hline Maize & 13 & 11 \\
Wheat & $13-14$ & $11-12$ \\
Barley & 13 & 11 \\
\hline
\end{tabular}

\section{PROSES PRODUKSI}

\section{Grain dryers}

Basically, drying process requires heat energy obtained from various sources. Energy is obtained from natural heat energy (the sun) or from energy sources that come from other energy such as diesel or geothermal. In this study, heat energy is obtained from waste fluid geothermal energy. This energy will heat the air in a room designed as a drying room. Heated air will cause changes in grain mass with time. Temperature of the air in the room must be adjusted to the 
temperature needed for the evaporation process in the grains. This is done to avoid drying output that is not in accordance with predetermined standards (Kinyanjui, 2013).

Drying chamber design for drying rectangular granules with a recommended air flow of 2.94-3.92 $\mathrm{m}^{3} / \mathrm{minute}$ per ton. If the moisture content in the grains reaches $18 \%$, then the layer where the granules are dried must not be higher than 3 meters. The area for hot air entry must be $15 \%$ of area of drying room (Kinyanjui, 2013).

\section{Drying Rate and Temperature}

The drying rate is directly proportional to the increase in air temperature in the drying room. Drying rate can be empirically formulated as follows:

$$
M_{e q}=0.01 *\left[\frac{L N\left(1-r h_{a m b}\right)}{-8.65 .10^{-5}\left(T_{a m b}+49.810\right)}\right]^{\frac{1}{1.8634}}
$$

$\mathrm{rh}_{\mathrm{amb}} \quad=$ Relative humidity of ambient air

$\mathrm{T}_{\mathrm{amb}} \quad=$ Temperatur ambient $\left({ }^{\circ} \mathrm{C}\right)$

Optimum temperature for the granular drying process is $49^{\circ} \mathrm{C}$

\section{Drying Tool Process and Design}

Pilot project for direct use of geothermal energy to dredge some of these commodities will be carried out when unit 1 of the Menangai geothermal power plant is operational. The Menengai geothermal field is located near the Kenya government drying area in Lesiolo area, Nakuru. The energy source for drying in this area still uses energy from diesel. Figure 2 shows the flow diagram of the remaining fluid supply from the separator and cooling tower to dry out several commodities such as wheat, corn and barley. 


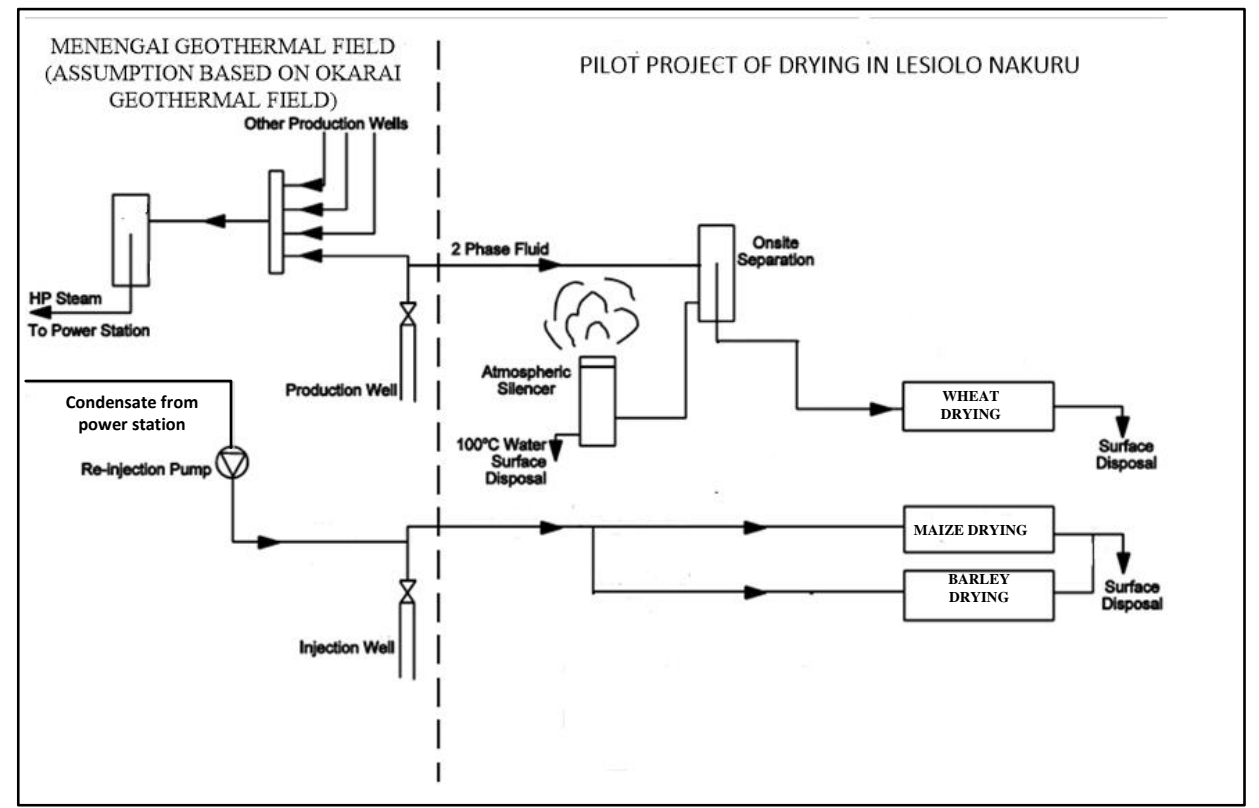

Figure 2. Flow diagram for brine and condensate supply to the Pilot Project drying in Lesiolo, Nakuru (Assumptions based on the utilization system mechanism in the Okarai geothermal field

Heat from remaining fluid will go into a heat exchanger in each type of commodity to be drained. Design of the dryer is very dependent on the drying method used. In this pilot project a static batch dryer type is used. Components of this design consist of drying rooms, air distribution systems, indirect air heating systems and blowers.

One drying room can hold about 20 tons in ambient air conditions. This dryer is shaped like a tunnel where hot air will flow from each side of the drying chamber. This system is very suitable for drying commodities that have high moisture content (Kinyanjui, 2013).

Drying temperature is very dependent on characteristics of each product. Hot air will be circulated through a blower to drying room. During initial stages of drying, moisture present in commodity will experience evaporation. When surface moisture has been lost, outside of commodity will dry up and rate of drying of the commodity will be inhibited (marked by heating surface temperature of commodity. Some of commodities studied in this pilot project have different drying temperatures. Wheat has a drying temperature of around $60^{\circ} \mathrm{C}$ then corn and barley have a drying temperature of about $65^{\circ} \mathrm{C}$ and $43^{\circ} \mathrm{C}$ (Kinyanjui, 2013) Figure 3 shows design of a drying system that gets heat energy derived from disposal fluid utilizing geothermal energy for electricity.

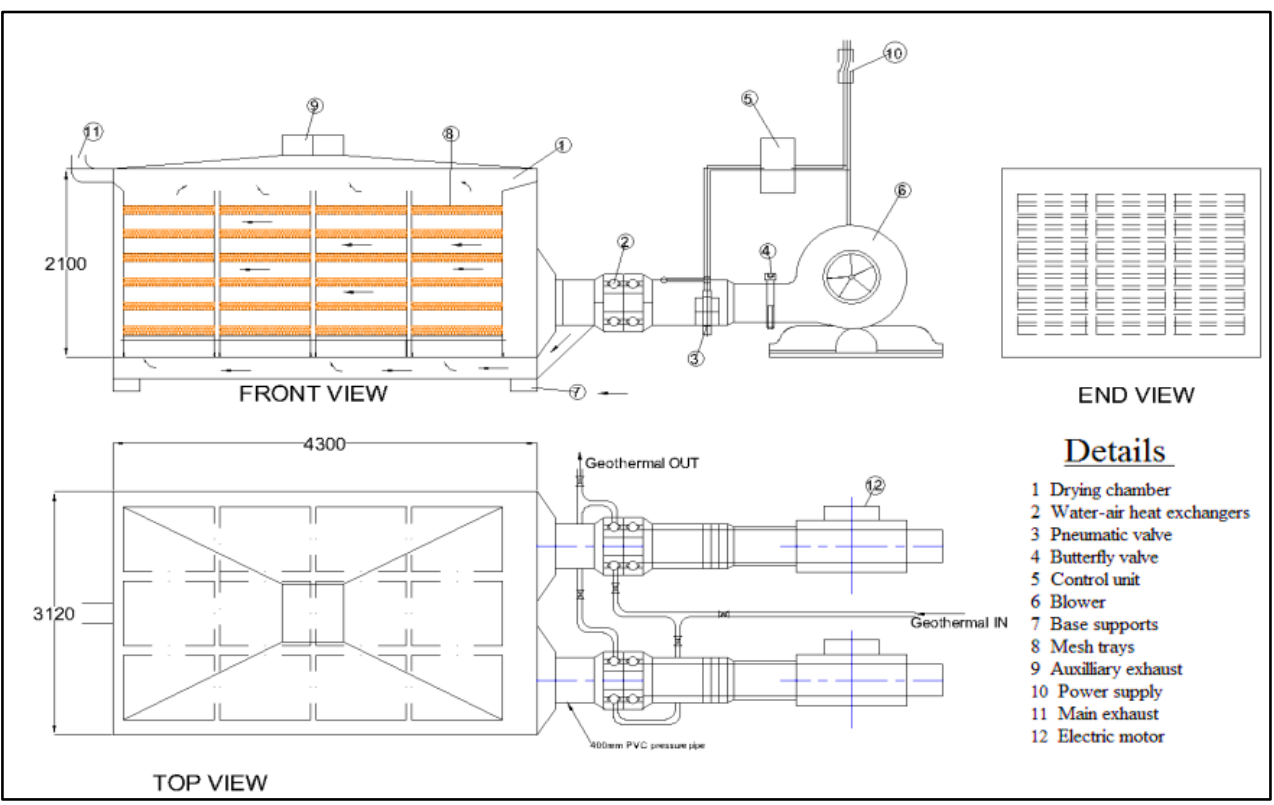

Figure 3. Drying design for each commodity (Kinyanjui, 2013) 
In process of drying corn, hot air is flowed to heat exchanger at an ambient temperature of $19^{\circ} \mathrm{C}$ and heated to $65^{\circ} \mathrm{C}$ and out of drying room at a temperature of around $50^{\circ} \mathrm{C}$. Regulation of heat flow to water heat exchangers is very necessary in order to get high-quality drying commodities. Based on assumptions and calculations that have been done, parameters needed for a drying device are obtained.

Table 2 Drying input design and calculation results (Kinyanjui, 2013)

\begin{tabular}{|c|c|c|c|}
\hline \multicolumn{4}{|c|}{ Inputs } \\
\hline \multirow{5}{*}{ Grain } & Parameter & Units & Value \\
\hline & Initial moisture content $(\mathrm{db})$ & $\%$ & 27 \\
\hline & Final moisture content $(\mathrm{db})$ & $\%$ & 13 \\
\hline & Grain drying temperature & ${ }^{\circ} \mathrm{C}$ & 49 \\
\hline & Grain density & $\mathrm{kg} / \mathrm{m}^{3}$ & 721 \\
\hline \multirow{2}{*}{ Dryer } & Volume & $\mathrm{m}^{3}$ & 30 \\
\hline & Type: Tunnel/tray & - & - \\
\hline \multirow{3}{*}{ Air } & Ambient temperature & ${ }^{\circ} \mathrm{C}$ & 19 \\
\hline & Relative humidity & - & 0.68 \\
\hline & Atmospheric pressure & $\mathrm{kPa}$ & 88 \\
\hline \multirow{3}{*}{ Geothermal } & Entry temperature & ${ }^{\circ} \mathrm{C}$ & 130 \\
\hline & Exit temperature & ${ }^{\circ} \mathrm{C}$ & 93 \\
\hline & Flow rate & $\mathrm{kg} / \mathrm{s}$ & 2 \\
\hline \multicolumn{4}{|c|}{ Calculations } \\
\hline \multirow{7}{*}{ Dryer } & Mass of grain dried & tonnes & 15 \\
\hline & Evaporated moisture & tonnes & 2 \\
\hline & Thermal energy & $\mathrm{kWt}$ & 250 \\
\hline & Drying time & hours & 7 \\
\hline & Quantity of geothermal used & tonnes & 40 \\
\hline & Air velocity & $\mathrm{m} / \mathrm{s}$ & 0.5 \\
\hline & Static pressure & $\mathrm{mm} \mathrm{H}_{2} \mathrm{O}$ & 300 \\
\hline \multirow{2}{*}{$\begin{array}{l}\text { Heat exchanger } \\
\text { (water-air) }\end{array}$} & Max. operating pressure & bars & 24 \\
\hline & Number of fins & - & 12 \\
\hline \multirow{4}{*}{$\begin{array}{l}\text { Centrifugal } \\
\text { blower }\end{array}$} & Air flow rate & cubic $\mathrm{ft} / \mathrm{min}$ & 14000 \\
\hline & Static pressure & $\mathrm{mm} \mathrm{H}_{2} \mathrm{O}$ & 400 \\
\hline & Motor rating & HP & 30 \\
\hline & Operating temperature & ${ }^{\circ} \mathrm{C}$ & 150 \\
\hline
\end{tabular}

In this study measurements were taken to determine relationship between geothermal fluid flow and drying time of maize commodities. From Figure 4 it can be analyzed that drying time is affected by amount of moisture content that must be evaporated and type of commodity. Production in large quantities is recommended to use a longer drying time assuming pipe used is small. Figure 4 also shows that rate of geothermal fluid flow decreases as drying time increases.

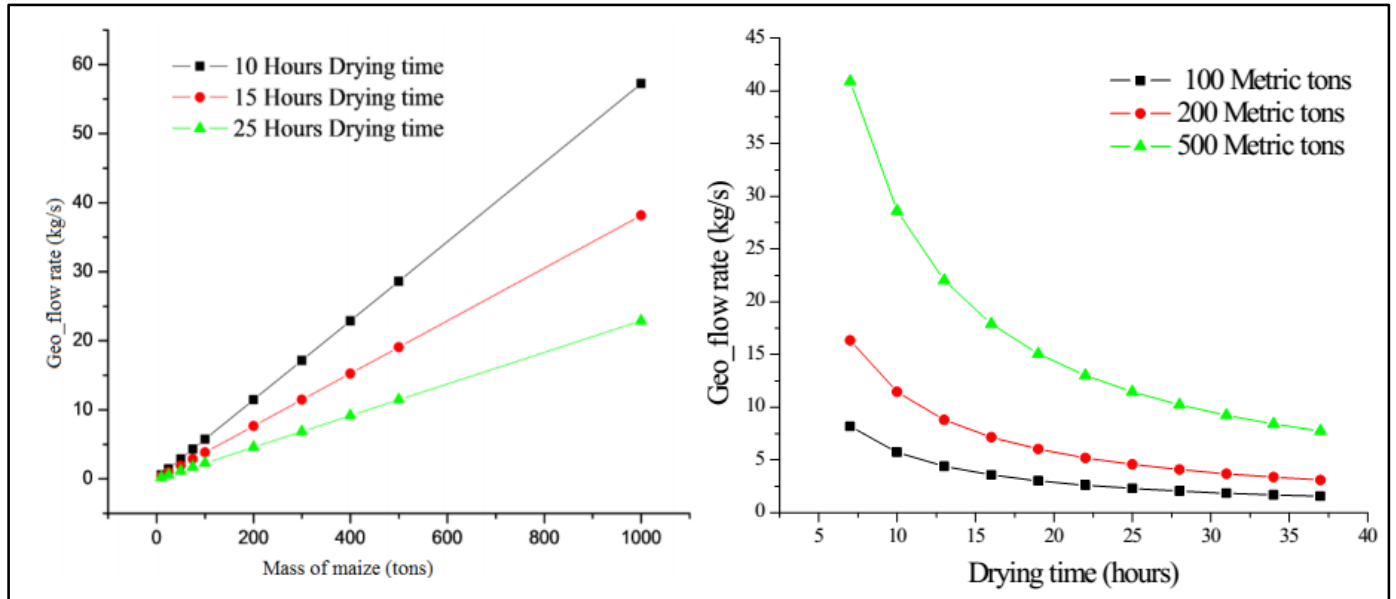

Figure 4 Variation of geothermal fluid mass flow for some masses from corn (left) and the relationship between mass flow with some grain capacity (right)(Kinyanjui, 2013) 


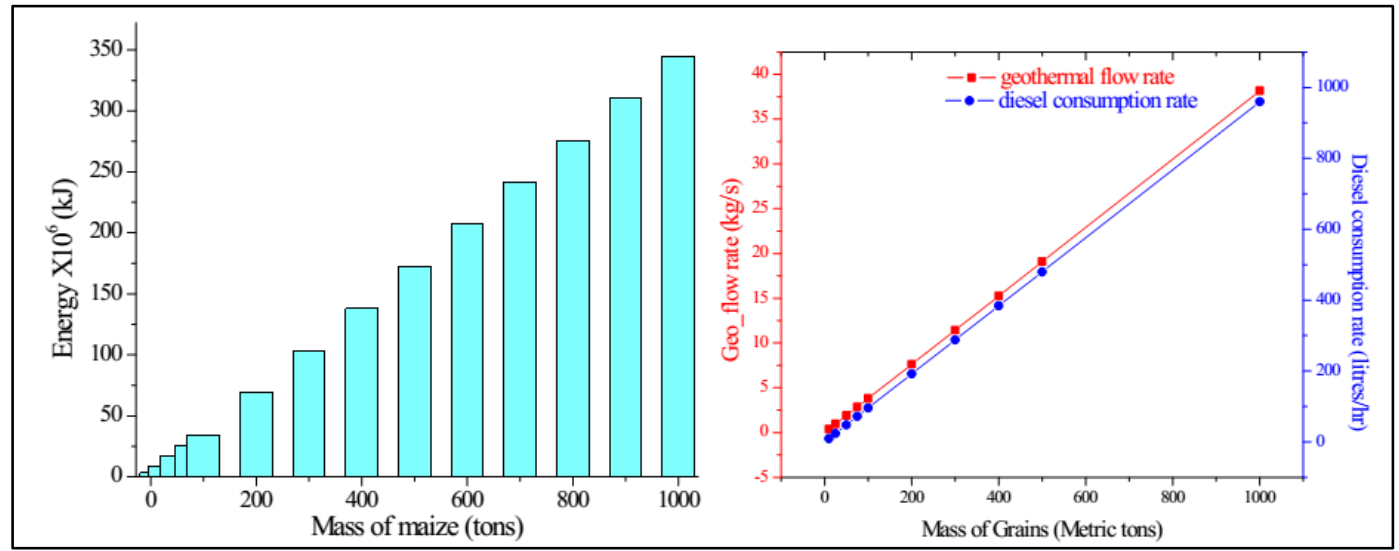

Figure 5 Energi panas yang dibutuhkan untuk variasi massa jagung (kiri) dan perbandingan antara penggunaan diesel dan energi geothermal (Kinyanjui, 2013)

Figure 5 shows the heat energy needed to dry corn. The greater drying capacity, greater heat energy needed. When compared between heat consumption derived from geothermal flow rate with diesel fuel, it appears that there is a similarity in consumption of each energy use. This shows that conversion of use of diesel fuel to use of geothermal energy is very possible from a technical perspective. However, this must be validated from an economic perspective so that pilot project can be a driver of agricultural sector in Kenya.

\section{RESULTS AND DISCUSSION}

Based on results of studies on the potential development of drying sector by using geothermal field waste fluid which will operate in Menangai, Kenya, it can be concluded that use of such heat sources for the drying process of food crops such as wheat, corn and barley can be done from a technical perspective. Fluid temperature disposal requirements required when entering heat exchanger are at least $130^{\circ} \mathrm{C}$ (inlet temperature) and $93^{\circ} \mathrm{C}$ (outlet temperature). Waste fluid mass flow rate needed is $2 \mathrm{~kg} / \mathrm{s}$. The calculated output is used to dry every $10 \mathrm{~m} 3$ of food commodities.

\section{Reference}

A.Omenda, P. (2007). Status Of Geothermal Exploration In Kenya And Future Plans For Its Development. Geothermal Training Programme.

Kinyanjui, S. (2013). Direct Use Of Geothermal Energy In Menengai, Kenya: Proposed Geothermal Spa And Crop Drying. Geothermal Training Programme (P. 9). Iceland: United Nation University.

Pirrit, N., \& Dunstall, M. (1998). Drying Of Fibrous Crops Using Geothermal Steam And Hot Water At The Taupo Lucerne Company. Geothermal Institute, The University Of New Zealand.

Wetang'ula, G. N. (2012). Geothermal Energy Development \& Potential Biodiversity Conservation And Tourism Development: Examples From Kenya. Geothermal Training Programme. 